\title{
Ichthyosis Acquisita
}

National Cancer Institute

\section{Source}

National Cancer Institute. Ichthyosis Acquisita. NCI Thesaurus. Code C112831.

A non-hereditary form of ichthyosis characterized by plate-like scales on the legs, arms and occasionally the torso. 